\title{
MINUTES OF THE MEETING OF THE BOARD OF DIRECTORS OF A.C.R.L.
}

THE Board of Directors of the Association of College and Reference Libraries met at breakfast in the Drake Hotel in Chicago on Saturday morning, Dec. 29, 1945, at 8:30 A.M.

Directors present were: President, Blanche Prichard McCrum; Vice President, E. W. McDiarmid; Past-President, Winifred Ver Nooy; Treasurer, Mrs. Vera Southwick Cooper; Secretary, Charles V. Park; A.C.R.L. directors, Ralph Eugene Ellsworth and Stanley Pargellis; directors representing sections; Fina C. Ott, for College Libraries; Marguerite $M$. Chamberlain for William N. Seaver of Engineering School Libraries; and Mary Floyd for Libraries of Teacher-Training Institutions. Section chairmen present were: Nellie M. Homes for the chairman of College Libraries; Eleanor W. Welch of Libraries of Teacher-Training Institutions; and Carl W. E. Hintz for the chairman of University Libraries. Others present, by invitation, were Carl M. White, editor of College and Research Libraries, and Eugene $\mathrm{H}$. Wilson, of the University of Colorado Libraries. $\mathrm{Mr}$. Wilson had been elected chairman of the University Libraries Section and was present in that capacity.

President $\mathrm{McC}$ rum opened the meeting by telling of the request of Mr. Milam that we appoint a representative to serve with representatives of the other divisions of the A.L.A. on a committee to advise with Mr. Milam on the selection of a successor to Julia Wright Merrill on her retirement in the near future. This committee will also consider with $\mathrm{Mr}$. Milam the reorganization of the Department of Information and Advisory Services of the A.L.A.

President McCrum was authorized to appoint a representative in compliance with the above request.

The discussion which followed brought out the fact that there is general dissatisfaction with our organizational setup as a division of the A.L.A. It was pointed out that the A.L.A. plan to reorganize their information and advisory services would not give us the kind of representation at A.L.A. Headquarters that our members want. Dr. White stressed the necessity for continuity of service in order that long-range plans can be made and carried through. It was suggested that it might be best for our division to have its own executive secretary. It was pointed out that we will have no funds to finance an executive secretary as long as we receive only 20 per cent of the dues paid by our members while the A.L.A. retains 80 per cent.

Because of these and other dissatisfactions voiced in the discussion, it was moved and seconded that the board appoint a committee to study the relationship of the A.C.R.L. with the A.L.A. This motion was passed unanimously.

It was obviously the desire of the board that this committee should make a thorough study of our organization. In order that the work of the committee should not be hampered by lack of funds, the board voted to authorize the committee to spend up to one thousand dollars if that sum should be required to complete the study.

Further board action requires the committee to report back to the board with recommendations for action as soon as possible. The hope was expressed that a progress report could be made at the Buffalo meeting in June.

One specific item to be considered by the committee is the proposal for a college library specialist at A.L.A. Headquarters.

Since the A.L.A. is now planning a reorganization of its information and advisory services, the board suggested that President McCrum request the A.L.A. to delay final action until our committee has completed its study.

The board next proceeded to select the committee. The final selections were as follows: Charles H. Brown, chairman, Mary Floyd, A. F. Kuhlman, Clarence S. Paine, and Stanley Pargellis. Dr. White, editor of College and Research Libraries, and Secretary Park were designated to serve as advisers to the committee. It was also specified that the secretary should be supplied with all papers and proceedings of the committee, in order that they may be kept as a permanent record. 
President McCrum was authorized to make further selections if any of the above designated persons is unable to serve.

It was further suggested that the chairman of each section be invited to advise with the committee.

It was suggested that a roster of our members showing interests and qualifications of each one should be compiled for use in selecting committees. Although no official action was taken, the suggestion received general approval.

Several persons expressed appreciation for the service rendered the association by College and Research Libraries. Voted to commend College and Research Libraries.

After a vote of thanks to President McCrum, the meeting adjourned.

Charles V. Park, Secretary

\section{New Periodicals of 1945-Part II}

\section{(Continued from page 155)}

Vt. v. I, no. I, Autumn 1945. Quarterly. \$4. New York Folklore Quarterly. New York Folklore Society, I 24 Roberts Pl., Ithaca. v. I, no. I,

February r 945. \$1.50.
Northern Review; New Writing in Canada. 635 St. Paul St. W., Montreal, Canada. v. I, no. I, December I945-January ro46. Bimonthly. \$2.

Orbe: Revista Latina de Cultura General. Palma Norte 335, Desp. 402, México, D.F. Año I, no. I, July 1945. Monthly. \$20 (for 6 nos.).

Pacific. Box 467, Mills College, Oakland 13, Calif. v. I, no. I, November 1945. 4 times a year. \$2.

Pictura; Revue d'Art Ancien et Moderne. Librairie Falk Fils, 22 Rue des Paroissiens, Bruxelles. v. I, no. I, January 1945. Quarterly. I8ofr.

Polymer Bulletin. Bureau of High Polymer Research, Polytechnic Institute of Brooklyn. Interscience Publishers, Inc., 215 Fourth Ave., New York City 3. Bimonthly. $\$ 2.40$.

Portfolio; $A n$ International Quarterly. Black Sun Press, Washington, D.C. v. I, no. I, Summer 1945. Price varies.

Renascence. Usher Society, 325 W. I Ith St., New York City 14. v. I, no. I, August 1945. Bimonthly. \$1.25.

Revista de Guatemala. Apartado Postal 404, Guatemala, C.A. v. I, no. I, July r945. Quarterly. Q.1.50.

Revista Industrial de Säo Paulo. Federaçäo das Industrias do Estado de Säo Paulo, Rua Baráo de Itapetininga, 273, Säo Paulo, Brazil. v. I, no. I, December 1944. Monthly. 6o $\mathrm{Cr}$.
Revista Musical Chilena. Instituto de Extension Musical, Universidad de Chile, Santiago de Chile. Año I, no. I, May 1945. Monthly. \$40.

La Revue de L'I.F.A.L Institut Francais d'Amerique Latine, Nazas 43, Mexico, D.F. Année I, no. I, June 1945. Quarterly. \$40.

The Screen Writer. Screen Writer's Guild, Inc. I $655 \mathrm{~N}$. Cherokee Ave., Hollywood 28, Calif. v. I, no. I, June 1945. Monthly. \$2.50.

Sociedad Venezolana de Historia de la Medicina.

Caracas, Venezuela. v. I, no. I, 1945. Frequency
C. and price not given.

Southwestern Journal of Anthropology. University of New Mexico Press, Albuquerque. v. I, no. I, Spring 1945. Quarterly. \$4.

Theatre. Bradford Civic Playhouse, Chapel St.,

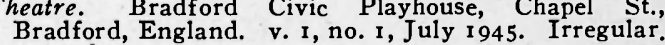

Theatre Notebook: $A$ Quarterly of Notes and Re. search. 32 Shaftesbury Ave., London, W. I. v. I, no. I, October 1945. Price not given.

The Trollopian; A Semiannual Journal Devoted to Studies in Anthony Trollope and His Contempo. raries in Victorian Fiction. University of California Press, Royce Hall 310, Los Angeles 24. no. I, Summer 1945. \$1.75.

The United States Ouarterly Book List. Issued by the United States Library of Congress, Superintendent of Documents, Washington 25, D.C. v. I, no. I, March I945. \$1.50.

Word: Journal of the Linguistic Circle of New York. 66 Fifth Ave., New York City II. Three times a year. \$3. 


\section{The Place of College and Reference Library Service at A.L.A. Headquarters: A Symposium}

For some time members of the A.C.R.L. have been concerned with the development I of a service at A.L.A. Headquarters which would concentrate its activities on problems of college and reference libraries. Because the questions involved in the establishment of such a service are significant and are being currently discussed, the editors of College and Research Libraries have arranged for a symposium to assist readers in evaluating the present situation. The first two papers, by Ralph A. Ulveling and Carl H. Milam, describe the recent actions of the American Library Association to provide increased service to college and reference libraries. The other statements represent views of members of the association on the desirable form of the service to be provided. At its meeting in Chicago, Dec. 29, 1945, the board of directors of the A.C.R.L. appointed a committee to study the relationship of the A.C.R.L. with the A.L.A. Members of the committee are Charles H. Brown, chairman, Mary Floyd, A. F. Kuhlman, Clarence S. Paine, and Stanley Pargellis.

\section{American Library Association}

For several years I have known that the establishment of a college library advisory service at A.L.A. Headquarters was not only an ambition of many librarians but was felt by some to be an urgent need. I had and still have a sincere desire to see this become an accomplished fact.

Very shortly after assuming my present office I set out to cut the Gordian knot-if such there was-that retarded this development, keeping in mind of course that the just rights of other groups in the Association would have to be fully respected also. Thus, in a spirit of providing equal opportunity for all, I proposed, within two months after my induction as President, that the existing advisory services for public libraries and school libraries be dissolved as such and that the resources which had maintained them be merged in one over-all department which would render comparable services to every group within the Association. In the original proposal it was stipulated that if and when increased funds became available the informational services of that unit should be expanded until, eventually, highly specialized advisory services for all would be realized.

At no time was I so naive as to believe that the proposed reorganization would at this time add to the aggregate of services provided by the Headquarters organization. Neither did I believe that the new plan would accomplish now the creating of fully adequate advisory services of the type desired for college librarians or for similar groups. It was simply a plan to divide what was available in an equitable way so all would share in its benefits. I shall be extremely disappointed if this doesn't give to college librarians more than they have had before. I believe it will.

In preparing this proposal I consciously and deliberately did not allow decisions of earlier years to influence what I believed to be the proper equities to be achieved at this time. Progress through the years ahead cannot be made in that way. Further, it would be in extremely bad taste for a current officer to adopt such a principle, just as it would be in equally bad taste for any member of the Association to suggest that the incumbent ad- 
ministration should distort its best efforts to serve the membership by following so sterile a policy as one of compensating for decisions which were made in good faith by others in earlier years.

Though the recommendation referred to above is admittedly inadequate for the needs, it is nevertheless realistic. On December 29 I presented to the Council a brief review of the financial limitations under which the Association's general activities must operate. Though the full text of that report appears in the February 1946 A.L.A. Bulletin, the high points of it can be given in a few sentences.

r. Income from the two-million-dollar endowment fund has, because of general economic conditions, shrunk from the $\$$ roo,ooo originally expected to about $\$ 73$,ooo. Obviously, $\$ 27,000$ worth of planned services have had to be sur-

N JUNE 23, 1945, representatives of the Board of Directors of A.C.R.L. met with officers of the A.L.A. on invitation of the latter. The conclusions, after a lengthy conference, were summarized as follows:

The Executive Board representatives were not only sympathetic to the establishment of this new service but recognized that the establishment of the service is an obligation to which the Association is committed. The officers stated that the Association is also definitely committed to the establishment of a research and statistical service and are convinced that a major expansion of the personnel activities and placement service is an obligation which cannot be avoided.

The income next year will apparently be a little less than it has been this year. There is no opportunity to provide funds for any of these activities out of regular funds unless certain other essential activities are discontinued.

The board is definitely committed to a policy of getting more funds rather than attempting to squeeze tighter the present limited budgets. It has engaged a man to represent it in opening up possible sources of funds and actually soliciting funds. The object is to obtain funds for general purposes, if possible; for special purposes, if they are not available for general purposes. Among the specific purposes at the top of the list is the college library advisory service. If general funds are obtained, the college library advisory service would be rendered during the intervening years.

2. Due to payments made to divisions under the new Constitution, the net income from membership dues, taking into account additional costs of operation under the new dues scale, is several thousand dollars less than five years ago.

3. Unit operating costs, because they are far higher today than formerly, have tended to shrink further the activities that can be maintained on the Association's income.

Despite these harsh facts, I have endeavored to strengthen the services that could be provided to divisions not formerly represented directly on the Headquarters staff. Any more productive plan which will be fair to all the diverse interests within the Association would be welcomed. With the greatest sincerity I invite your constructive help in this, a common problem.

Ralph A. Ulveling

among the first to benefit from them.

The officers of the A.L.A. expressed their desire to have A.C.R.L. participate in planning the activities and projects which will be of special interest to college and university libraries and also to participate in the soliciting of funds which will make such activities possible.

On invitation of the President of the A.L.A. representatives of A.C.R.L. met on October 5 and 6 with the Budget Committee. There were also representatives of three or four other groups which were asking for funds.

The Budget Committee was "impressed with the gravity of the financial situation and convinced that the activities of the A.L.A. will suffer increasingly unless means can be found to increase substantially the income of the Association." It deplored particularly its inability to find funds for the salary of an associate secretary, commended the Executive Board for its efforts to find new sources of income, suggested that the Fourth Activities Committee "study the existing organization of the Headquarters staff, the services provided by each department and each person in Headquarters, to the end that present activities may be evaluated and justified, not only as to the professional need and service of each, but with special reference to legitimate demands which the present budget could not meet." 
The Budget Committee recommended reorganization of the Department of Information and Advisory Services and a discussion with the divisions of the question of their assisting in providing funds for the department. It recognized that the budget, as prepared, made less provision than usual for public library advisory service. The members of the committee were Ralph A. Ulveling, Mary U. Rothrock, Rudolph H. Gjelsness, and Robert A. Miller.

The Executive Board at its meeting in October considered these matters at length, approved in general the recommendations of the Budget Committee, and specifically instructed the Executive Secretary to prepare a plan for reorganization of the Department of Information and Advisory Services for the consideration of the board and of the representatives of the divisions during the Midwinter Conference. By Executive Board vote I was instructed to include provision "for a librarian with such other professional and clerical assistance as the combined budget will allow."

The memorandum was prepared and submitted for criticism to the members of the Executive Board and representatives of divisions in advance of the Midwinter Conference. In somewhat revised form it was discussed at length at the meeting of the divisional representatives with the Executive Board on December 27. The memorandum sets forth in detail the information which is summarized above. It included the following paragraph under

Purposes. In preparing this memorandum I am trying to keep in mind two desirable objectives or purposes: ( $x$ ) To make the services of the Headquarters Department of Information and Advisory Services as useful as possible to all types of libraries and to all librarians, with special concern for equalizing the service to the various groups; (2) To provide a basis for a more unified attack on important problems by the divisions and the A.L.A. in general.

Under the heading "Information and Advisory Services-Definition," the memorandum referred back to the "Program for the American Library Association, 1932," which was prepared by the Executive Board and officially adopted by the Council. (See February 1932 A.L.A. Bulletin.) Presented as exhibits were brief memorandums on the present activities of the three professional staff members in the department. The nature of the work is briefly indicated by the following words and phrases: information service, advisory service, promotion, field work, work with divisions, work with boards and committees.

The most difficult problem dealt with in the memorandum and in the discussion at the meeting concerned finances. The Budget Committee and the Executive Board, after most careful and sympathetic consideration, were able to appropriate only $\$ 26,886$ for the Department of Information and Advisory Services. This provides a payroll for three professional and three secretarial assistants and for the other expenses of the department on a very limited scale. In order to represent public libraries, school and children's libraries, college and reference libraries, and continue the A.L.A. Library, we would need as a minimum $\$ 7500$ more for one professional and one clerical assistant, supplies, postage, and travel.

How this financial situation came about may be briefly explained as follows:

When the "program" referred to above was adopted, we expected to be able to spend $\$ 125,000$ annually for general purposes after the $\$ 2,000,000$ endowment had been secured and invested. This was based on estimates of endowment income, $\$ 100,000$; special memberships, $\$ 25,000$. This year these items total, not $\$ 125,000$, but about $\$ 96,000$. The differential of $\$ 29,000$ is further increased if one takes into account the increase in costs between 1932 and 1945-46. The reasons for decreased income for general purposes are: (I) The $\$ 2,000,000$ endowment is now producing, not $\$ 100,000$ as anticipated, but $\$ 73,000$; (2) During the past six years, average annual underwriting of other budgets by the Membership Department has been about $\$ 10,500$. (It is approximately $\$ 23,000$ this year for several reasons, two of which are: prospects for a large conference which will yield large income from exhibits; and the existence of balances last September I because of inability to keep positions filled during the war. The total income for general purposes for 1946-47 may be considerably less than $\$ 96,000$.)

Appropriations by divisions had been suggested. Attention was called to the fact that it would take approximately all of the budg- 
eted allotments to all divisions for one year to provide the minimum of $\$ 7500$.

Increased membership was suggested as a real possibility. A dues dollar is now used about as follows:

For membership records and activities $\$ .37$

For A.L.A. Bulletin

For divisional allotments

For underwriting other activities

.30

.08

.25

$\$ 1.00$

New membership dues income in large volume should yield a slightly larger amount for other activities, say thirty cents out of each dollar. If we could, at once, add $\$ 25,000$ from this source, the Membership Department could soon increase its underwriting by $\$ 7500-$ ("soon" rather than "immediately" because it costs more to "process" a new membership than a renewal). As the average member pays in a little more than four dollars, this would mean about six thousand new members.

Obviously, with present income or with a somewhat expanded income, it will be impossible for the Department of Information and Advisory Services to perform all of the possible and desirable activities which are suggested by the words "information," "advice," "promotion," etc., even in the two or three or four special fields nominally covered. I, therefore, suggested that there be created a standing committee or board which would serve in an advisory relationship to the department; the committee to be made up of one representative chosen by each division for fiveyear staggered terms; the committee to meet at least twice a year at annual and midwinter conferences, and possibly at other times, with the staff of the department and the Executive Secretary to discuss the work of the members of the staff and to help determine from time to time what the emphasis should be.

It was thought that, through the establishment and use of this machinery, we should be able to bring about a desirable coordination of emphasis as between the A.L.A. and the divisions, a large degree of flexibility in the work of the department from year to year, and variations in the emphasis for the different subject specialists in the same year. Such a committee or board would be in a position to make recommendations to the budgetary authorities and to the profession and would have large responsibility for determining the nature of the work to be done by the department within the limits of the budgets actually provided.

Most of these matters were discussed in some detail at the meeting. No very satisfactory solutions were found. Provision was made, however, to continue the discussions. The group recommended and the Council later approved

The creation of a special committee to confer with the officers with a view to determining how the Department of Information and Advisory Services can be reorganized and developed to serve better the needs of the whole profession, with special emphasis on the needs and interests of the divisions, the committee to be appointed by the Executive Board on the nomination of the divisions.

At this writing, January 8 , I have been informed of several nominations by divisions. Ralph Eugene Ellsworth is to represent A.C.R.L. I am planning to arrange for a meeting of this group as soon as possible and shall make no recommendation to the Executive Board concerning a successor to Miss Merrill, who retires in the spring, until after the group has considered the whole problem of reorganization.

In the meantime, we are launching a vigorous campaign for new members, not a few hundred, but several thousand. With the help of the divisions and individual members and under the leadership of the reorganized Membership Committee headed by Althea $\mathrm{H}$. Warren, we ought to succeed. We are also continuing our search for new sources of income. All officers are convinced, as are members of the much-criticized Budget Committee, that the only satisfactory solution is more money for general purposes.

Carl H. Milam

\section{General Statements}

Commentators quite generally have difficulty in distinguishing fact from fiction. The difficulties are more serious when com- ments are invited on proposed legislation which has not yet taken form.

The Executive Board of the A.L.A. and 
representatives' of divisions at a meeting on Dec. 27, 1945, passed the following resolution:

VOTED, That this group recommend to the Council the creation of a special committee to confer with the officers with a view to determining how the Department of Information and Advisory Services can be reorganized and developed to serve better the needs of the whole profession, with special emphasis on the needs and interests of the divisions, the committee to be appointed by the Executive Board on the nomination of the divisions.

We understand that the position of chief of the Public Library Office is to be abolished upon the retirement of Miss Merrill; that the positions of school and children's library specialist and of the Headquarters librarian will be abolished insofar as such titles are concerned; and that a new department will be organized to include the information and advisory services to the profession at large. It is estimated that twenty-five thousand to twenty-six thousand dollars will be available for the functioning of the reorganized department, but that this sum will not be sufficient to cover the salaries of four specialists and their assistants-college, public, school and children's, and Headquarters librarian. One proposal was to invite the various divisions to contribute to the support at Headquarters and, through this means, raise the additional $\$ 7500$ required.

In the meantime, at a meeting of the A.C.R.L., an animated discussion followed the presentation of a paper by A. F. Kuhlman. Speakers criticized in general the present relations of A.C.R.L. and A.L.A., but the only constructive action which resulted from the meeting seemed to be the appointment of an A.C.R.L. Committee to Study the Relations of A.C.R.L. to A.L.A., which was asked to make a progress report in June. In the meantime, Blanche Prichard McCrum, President of A.C.R.L., has written to President Ulveling, forwarding a statement from the Board of Directors of A.C.R.L. to the Executive Board of A.L.A. Her letter includes the following paragraph: "[The board of directors] welcome the necessary delay in reorganizing the information and advisory services at Headquarters. They request, moreover, that any present organization at Headquarters affecting the A.C.R.L. be kept an open matter until the committee has time to study and report upon the various possibilities."

A reading of an abstract of the discussions and a memorandum prepared by the Executive Secretary leaves one in a state of fog. A new information service should be organized to serve the profession at large, yet the Executive Board voted to abandon the collection of statistics for college, public, and school libraries. Certainly, statistics would seem to be about the most important factual information service which a national organization can render.

The Executive Secretary, in his memorandum, makes a very true statement of the saving which can be made by the use of divisional officers, boards, and committees.

Most A.L.A. divisions, in common with other organizations of similar size, now avoid the necessity of paying fully for services by getting volunteers to do the work. Frequently the libraries of the officers make considerable service contributions to the divisions. If these services are all performed by a paid staff, then it must be realized that A.L.A. or the division is paying for services formerly performed free of charge and that the amount available from both sources for information and advisory services is reduced by the amount of that cost. I hope our joint thinking, now and later, may help to resolve this problem.

The question immediately arises as to whether the same principle could not well be applied, possibly more than it is at present, to the boards and committees of the American Library Association.

Obviously, justified criticism has been caused by the fact that specialists in certain fields such as adult education, public libraries, and children's and school libraries were provided, when specialists could not be provided for fields seemingly equally important.

Any administrator of a large office which has been in existence for a number of years yearns for a thorough reorganization. The question naturally arises: Why was the reorganization limited to the Department of Information and Advisory Services? Why were not the Department of Library Education and Personnel, the Publishing Department, and the Department of Membership Organization and Information included in the proposed reorganization?

Before any reorganization is undertaken, it 
might be well to inquire what sort of a Headquarters staff does the Association want and what sort of services would it like to receive? To say that the more important of these services can be given only by an increase in the dues is begging the question since, if institutional dues are to be doubled, as has been proposed, to provide for a special statistical service, the question might naturally arise, "What do institutions receive in return for the dues already paid?" There is a limit to the charging of fees for special services. The time may come when the increase in institutional dues may result in a decided loss of institutional membership in the case of publicly-supported libraries.

Let us suppose, however, that increased funds can be obtained for a much enlarged Headquarters staff. How far do the members of the Association wish to go? How does the size of our Headquarters staff compare with the size of headquarters staffs of similar organizations when the number of members is taken into account? Do we want an enormous staff with specialists on all sorts of subjects? We have had proposals for many specialists at Headquarters, for an associate executive secretary, and for an office in Washington (which we now have). Many other suggestions could be mentioned as, for example, an office in New York to deal with book publishers. How far should we go? Do we want a Headquarters staff which may become the master of the Association rather than its servant? This question might well be threshed out by the membership at large.

The writer believes that, of all the services rendered by the A.L.A., placement and statistics are the most valuable, and these two should have been maintained on a high level of efficiency no matter what else suffered, unless some government department or other agency was prepared to take them over.

Another library association in this country was organized on the principle that a very small headquarters staff would be required and that the work of the association could be done chiefly by its officers, boards, and committees which receive small grants from the association. The association has conducted local meetings, especially in the metropolitan areas. It has obtained great loyalty and unity among its members. Its membership has increased from 2433 members in 1940 to 3836 members in 1945, an increase of 57 per cent. During the same period, the membership of the American Library Association has decreased from 15,808 in 1940 to 15,187 in 1945 . There is a lack of unity among the rank and file of its members in comparison with its sister association.

The membership of the College and Reference Section before the organization of the A.C.R.L. was 140 in 1936 . It increased after the organization of the A.C.R.L. to 761 in 1938 , and in 1944 the membership totaled 2162. These figures are impressive, but there are probably well over six thousand college and reference librarians in the United States who are eligible for membership, half of whom are not members of the A.L.A. Is there some arrangement through an amendment to the Constitution providing for an interchange of dues which would make it possible for the A.C.R.L. to bring within its fold those college and reference librarians who are not members of A.L.A.?

The war has naturally interfered with the functioning of the association. An unusually satisfactory journal was started early in the history of the association, thanks to the untiring efforts of A. F. Kuhlman. This journal is a credit to the association. The association might well operate with a number of active boards and committees and with a very small headquarters staff-say, an executive secretary or an assistant secretary on a part-time basis.

The writer does not believe that a college library specialist at Headquarters would fulfil the needs of this young and vigorous association. On the other hand, such an appointment may tend to interfere with the attainment of the great possibilities open to such an association.

It would be most desirable to study the relations of A.C.R.L. to A.L.A., and this study will be the chief work of the committee recently appointed. The writer is expressing his own subjective opinions, without time for a collection of data in regard to the discussions and crosscurrents now under way. He cannot speak for A.C.R.L. nor its officers and its board of directors. Very probably many of them would disagree with the opinions herein expressed, and the writer, naturally, reserves the right to alter his opinions as further data are obtained.

Charles Harvey Brown 
WHETHER OR NOT A.L.A. is to become really effective in the college, university, and research library field depends on its decision to make a place on the Headquarters staff for a specialist in that area. It is true that the Association has performed many services for "learned" libraries and has undertaken many obligations. But this activity is usually directed toward specific objectives, and the gun is aimed by an agency either created for a limited purpose or concerned with many targets, of which the research library aspect of a problem is only one of many. The Board on Resources of American Libraries is an illustration of the specific purpose agency; the Board on Personnel Administration-in its stimulating work on pay plans for libraries of institutions of higher education-exemplifies the multiple-target agency. Thus, while some useful building material is made, it never gets put together as a structure by a single integrative Headquarters agency.

This need has long been felt in the field. It is expressed in the rise of the College and Reference Section to divisional status as A.C.R.L.; it was a moving force in the origin of the Association of Research Libraries. That the sense of need has persisted so long is evidence of a lack in the present apparatus available to college and research libraries for united effort. This apparatus consists of A.C.R.L. and A.R.L. A.C.R.L. organizes conference programs and publishes this journal. It is a general organization, open to all in the business; A.R.L. is a limited agency as to number and kind. Its activities, intended primarily to benefit the largest research libraries of the country, do-often and incidentally-benefit college and the smaller research libraries. The large research libraries often have access to money for the furtherance of joint projects; the small libraries lack this advantage as individuals and must seek their support by union. Joint activities are easy to start; they continue with difficulty as they en- large and demand time endlessly. The only solution, if rapid accomplishment is expected, is paid personnel; in this case, a college and research library agency at A.L.A. Headquarters.

The advantage of combining for accomplishment is not the only consideration to be kept in mind. The great concentration of research libraries is in the northeast quadrant of the United States-really on the coastal strip between Boston and Washington where the conveniences of communication and travel produce a natural cohesion and cooperation. If research library activity is unorganized, or organized on a volunteer basis, responsibility naturally gravitates to this area. Thus, while research libraries of the country may benefit from the initiative of the Northeast, they have small opportunity to contribute or share in control. An active and positive central agency at A.L.A. Headquarters could appreciably improve such a situation by its representative character. Furthermore, such an agency, by its centrality in the affairs of research libraries, might pay a dividend by bringing to light, more quickly than now, persons in small libraries potentially valuable to the profession.

A central agency would be better able to maintain a close and valuable contact with the many associations at work on college and university problems, such as the American Council of Learned Societies, the American Council on Education, and the American Association of Universities. Finally, to end this casual catalog of anticipated benefits, provision through this agency of a focal point for college and university library interests should strengthen the case for adequate statistical reporting. It is peculiarly regrettable that no way has been found of continuing, during the war years, the minimum statistical tabulations formerly available. The need for such information, especially on salaries, is at the moment acute, in view of the rapidly altering wage situation in all lines of employment.

Donald Coney
A BELIEF that the American Library Association is primarily concerned with public libraries has long been firmly implanted in the minds of college librarians. A large body of evidence to the contrary, especially in the work of voluntary boards and committees and in the publication program, leaves them unconvinced, chiefly because the A.L.A. has never made provision for a full-time $\mathrm{Head}$ quarters staff member to look after the in- 
terests of scholarly libraries. Assuming that the present agitation for such a representative leads to the creation of the position, a number of basic questions remain to be answered.

In the first place, should the Headquarters specialist attempt to provide expert assistance for all types of higher educational institutions and reference libraries? If so, a veritable paragon will be required. Included in the seven sections of the Association of College and Reference Libraries are hundreds of junior colleges, teachers' colleges, liberal arts colleges, technical schools, every kind of university, and reference libraries ranging up to such organizations as the Library of Congress and the New York Public Library. For any one individual to cope with the varied problems presented by these highly diverse institutions would call for knowledge and experience possessed by few, perhaps no, members of the library profession. Rather than trying, therefore, to be everything to everybody, riding off rapidly in all directions, it may be sound tactics, at least at the outset, to concentrate attention on limited objectives. And, if limitations of scope are essential, as they seem to be, first consideration should doubtless be given to college libraries. Contrasted with the university and large reference libraries, the college group, as a rule, has smaller staffs, more limited resources, and greater need for outside help. Also, the interests of university and reference libraries are being looked after, to a far greater extent, by special organizations. In future years, as the functions of the Headquarters office expand, fortified by experience and experimentation, other specialists might be brought in to represent additional types of libraries.

Recognizing that, in the beginning, a wellrounded service for all educational and research libraries may be impracticable, there are still various ways in which the central office could be useful to each of the seven groups comprised in the A.C.R.L. For example, the office should be a focal point for information, printed or otherwise, on library government, organization, administration, architecture, equipment, finances, personnel, book selection, acquisition, cataloging, classification, circulation, reference, cooperation, and related topics. One of the primary duties of the staff specialist should be to assemble relevant data in these fields and make them available for consultation as desired. Furthermore, again assuming a single individual could not be omniscient in all subjects, the central office should have on file a record of persons, in or out of the library profession, whose special experience, training, knowledge, avocations, interests, or other qualities equip them to advise on matters outside the capabilities of the staff representative. (In short, if the latter does not know, he should be able to turn to someone who does know.)

As part of the function of gathering information, the Headquarters office might well serve as a depository for correspondence files of pertinent boards and committees. Much of the work of these volunteer groups is dispersed and lost, as members change and materials are scattered and discarded.

Ultimately, the activities in which the staff representative should engage are numerous and important. Naturally, he would keep in close touch with all sections of the A.C.R.L., and with such other A.L.A. groups as have a direct bearing on his work. He should serve as a coordinator to eliminate duplication of effort; stimulate needed publication, research, and investigation; help to plan and direct conferences; assist in library surveys; compile statistics; and develop standards. He would also be expected to establish and maintain cordial relations with and present the library point of view to the leading national and regional educational associations.

The success or failure of a Headquarters representative would hinge to a large degree upon the ability and personality of the person appointed. The probable salary ought to attract a capable young man, but without extensive experience. His qualifications should include enthusiasm, broad intellectual interests, sound professional training at least two years beyond college graduation, a desire to expand his knowledge, ability to work with all kinds of people, proficiency in writing and public speaking, and an attractive personality somewhat on the extrovert side-in brief, a younger $\mathrm{Carl} \mathrm{H}$. Milam. Having found such a wonder man and placed him in the national Headquarters limelight, the next problem would be to hold him in the job against the competition and in the face of alluring offers of positions from college and university libraries throughout the country.

Robert Bingham Downs 
THOSE of US who have urged the creation of an agency representing academic and scholarly libraries of all types within the A.L.A. structure must now be specific about our wishes and expectations and in general agreement as to our goals. In the recent past, some have merely been incensed at the alleged practice of "taxation without representation," some have held pious hopes of relief from time-consuming committee work, some have had in mind specific functions which the proposed agency would carry out, and, finally, some have looked to the agency to provide the kind of leadership that would raise us above the present level of dissatisfaction with ourselves. Those in the latter group express a wide range of expectations, with a simple, honest, and realistic conception of what an executive secretary can do at one extreme and a führer-like leadership complex at the other. In between, the majority look hopefully for someone to do something.

The points of view expressed in the following statement represent my own attitude, tempered as much as possible by what two dozen or so of my colleagues in academic and scholarly libraries have told me. I do not pretend to speak for university librarians in general or for any specific group in the A.C.R.L.

Primarily, what I and those with whom I have discussed the matter want is, first of all, our just share of the dues we pay to A.L.A., plus the use of our share of the A.L.A. endowment, made available to A.C.R.L. without strings, to be sent by A.C.R.L. in whatever way our organization thinks will benefit academic and scholarly libraries most. We do not object to A.L.A. handling our money so that individually and collectively we will not do away with it (being a new group we are, of course, not accustomed to handling large sums of money, although individually we may be responsible annually for rather sizable budgets), but we do not want any other group to tell us how we shall spend this money nor do we propose to see a large part of it whisked out from under our noses by an A.L.A. accounting system that may be logical as a system but illogical in effect. Specifically, if it cost $\$ 5000$ to publish a manuscript under A.L.A. sponsorship while the same could be published commercially for $\$ 1700$, we want the right to publish our own manuscripts com- mercially under our own sponsorship.

We do not wish to see a large share of our dues paid for A.L.A. activities that are not relevant to our work.

In other words, financially and otherwise, we wish to be unscrambled, and to be allowed to promote our own cause according to our best understanding, and we do not wish to stand in the way of other groups which wish to do likewise.

In one sense this means that we think the time has come when it is no longer wise for the A.L.A., as a single organization, to try to handle the affairs of all kinds of libraries without major and acute differentiation among the types. In another sense, this visualizes the A.L.A. more and more as an abbreviated federation of strong divisions, each promoting its own activities with its own studies in its own way.

We do not wish to use our share of our money for a headquarter's staff that will be an "action bureau." We want one, or one half of one, person who will be free to think and plan for A.C.R.L. in somewhat the same manner in which Waldo Leland acts for the American Council of Learned Societies. We want this person to recommend to A.C.R.L. the initiation of research and other studies and in general to do the things that will slowly but surely help us raise the level of our own accomplishments.

We do not want this person to do a great many things, or to try to make us do a great many things that sound important, but which get nowhere in the long run, because they are not geared to a continuous long-time consistent organization. In other words, we want less frenzied committee work on issues of the moment within A.C.R.L. and more planning of larger issues, and we want our representative to act in the same manner.

We expect the business of college and university librarianship to be handled by college and university librarians, not by our headquarters.

Just how we are to get the kind of autonomy, financial and otherwise, we want without creating a split in the American Library Association is not very clear at the moment, but let it be understood that the members of our group have little respect for the idea of unity in the A.L.A. when that unity is so artificial and the price of it so high. 
We are increasingly disturbed by the fact that many of our most intelligent and influential members see little use of throwing their efforts into A.C.R.L. as long as it is connected with A.L.A. on the present basis. These men are quick to size up the situation and are confining their professional activities to the Association of Research Libraries and other groups outside the A.L.A. We want this leadership kept within the A.C.R.L.

There are many in our group who are capable of carrying on the kind of research studies that are necessary if the level of academic and scholarly library service is to be raised. We want our A.C.R.L. organization to be the coordinating agency for our members and we want our A.L.A. dues to support these researches. In this way, we believe that in a very real sense we can help raise the level of library service in academic and scholarly libraries. We see little hope that our objectives can be reached at the present time under existing relationships.

In brief, I think many of us are not interested in the idea of a strong elaborate academic and scholarly library agency within the A.L.A. present structure. We do see the necessity of having our own money to spend under A.C.R.L. direction for substantial studies and projects. We see the necessity, perhaps, of a small headquarters organization that might or might not be located at A.L.A. Headquarters.

RALPH E. Ellsworth

\section{Sections of A.C.R.L.}

\section{Agricultural Libraries}

R URAL READING would be a field where agricultural libraries could exert needed leadership. It is a field which cries for work to be done. None of the national farm papers carries a book page or even a column, and we librarians know that the third of the nation, up to now without libraries or other book sources, is in the rural areas. So the farmer has not been able to get books, and his journalists, who know him fairly well, do not sense any demand from him for books. If this be true, it is a social weakness. If all of us are to prosper, the farmer must be brought into touch with our technical and social trends. Headlines and headline thinking from newspaper and radio will not accomplish this. Reading is needed, and yet it is too much to expect a farmer to read with profit even the carefully written government bulletins when reading, for him, is not an easy and practiced habit.

In the recent past it has been said that books were too expensive and so was rural library service. Many librarians still act as though this were true. In such thinking they are in a cultural and technological lag. The twentyfive-cent book is a financial success, now on sale everywhere and soon to appear all over the countryside in gas stations, general stores, by mail, etc. The cost will go down when war experience with soldier usage and mass production methods are applied in earnest. The small-town library and librarian catering mostly to fiction users is in imminent danger of obsolescence.

Granted the farmer has not in the past read with the same volume as other groups, yet his sons and daughters and, some years ago, his uncles and aunts have read as avidly as any, once they arrived in the city. The bookmobile staffs and the T.V.A. experiments testify to the ease of arousing rural interest in reading. The new fact is the twenty-fivecent book at last at hand to serve this interest at a price the farmer can pay. A rise in rural reading time and skill is certain to follow. Here is where the agricultural libraries can exert leadership and would find a centralized advisory service of great use. Such a service, with A.L.A. connection, could help the agricultural libraries act as a unit in dealing with publishers of inexpensive books, influencing choice of subject, selection of authors, distribution techniques, etc. If group action can help, agricultural librarians must not allow books at twenty-five-cents to become as completely a means for entertainment as have the motion pictures, only now slowly coming to educational use. Probably no one thing would make agricultural libraries more the powerhouses 
of rural improvement they should be than the rise in reading skill among rural people which a wisely directed use of inexpensive books can bring.

In regard to other areas of assistance, centralized A.L.A. advisory service to agricultural libraries must consider two complex factors. The first is the U.S.D.A., with its aggressive and skilful concern for agricultural matters, both general and bibliothecal. There is a temptation to say let the U.S.D.A. do the whole job. Certainly the department and its director of libraries, Ralph R. Shaw, have ideas and plans, even for general reading service. $^{1,2}$ But suppose we resist temptation and decide to work to keep the enterprise in private hands. Then a second factor will make a clear definition of many possible functions difficult to attain. This factor is the very nature of agricultural libraries. Actual$l y$, as a rule, these libraries gain their definition from serving agricultural clients rather than from clear subject specialization. An agricultural library may well have books and other stock on home economics, education, economics (including statistics), the sciences (physical as well as biological), and engineering, in great quantity. It may even be that, as library management problems, such literature may compete for library staff time and

\footnotetext{
1 A.L.A. Bulletin 36: 95-99, February 1942.

2 College and Research Libraries 4: 29-34, Decem. ber 1942 .
}

attention with the holdings in agricultural literature narrowly interpreted. This is due to the American situation which considers agriculture as much a way of life as a subject of impersonal study.

With these two factors in the agricultural libraries' situation understood, one may wonder what strictly library services an A.L.A. centralized advisory office could render. With the problems of building and equipment, acquisitions, cataloging, reference, and research, we could expect little of specialized help which is not now better given either by the U.S.D.A. libraries or by other library or commercial agencies. When these problems are of a special nature, particularly when of a subject nature, the U.S.D.A. is of great assistance; when the problems are the same as those of libraries in general or of libraries attached to university departments or research institutes, then the agricultural libraries have or need the same sources of help as general libraries or as special libraries. If A.L.A. can help any libraries along these lines it will be helping agricultural libraries. But the truly peculiar service of which agricultural libraries are capable, and which is not now given, is active educational leadership among the rural people. A.L.A. is fitted by its whole program to aid in this movement, and the advisory service would be an appropriate agency.

John H. Moriarty

\section{College Libraries}

College libraries especially need the service that an educational specialist at A.L.A. Headquarters might offer.

Advisory service is needed to help the college librarian interpret to the library committee and the administration the place of the library in a progressive program of higher education. This would necessitate a study of the status of a variety of college libraries and also a study of the best trends in college teaching and educational programs. Suggestions might be sent to the libraries calling for assistance. The specialist should be one who could meet administrators and faculty with understanding and convictions, in order to assist the librarian in integrating the library and educational program of the campus.

The college librarian needs statistical serv- ice. Statistics of colleges of varied sizes should be available for presentation to administrations, trustees, and faculty library committees to encourage increase in library budgets and the use of the library. Librarians need statistics to evaluate staff standards.

A centralized college service could initiate a study of the academic status and salaries of college librarians, and stimulate some improvements.

Many college libraries are developing valuable services. Many small college libraries need the inspiration of new ideas. The college headquarters office could serve as a clearinghouse of progressive methods and program for the information of librarians, including suggestions for integrating classroom 
instruction and reading programs, for teaching with books as well as for recreational reading.

College librarians now find it difficult to locate the details that they and administrators want in planning new buildings: the latest in plans and building materials, library architects with understanding of college building programs. The specialist at A.L.A. could provide a clearinghouse of such information.

The A.C.R.L. office might offer information on cooperative library services of value to college libraries.

College librarians want to know the developments in the field of higher education. College education specialists should be aware of the place of the library in educational programs. The specialist at A.L.A. should as- sociate himself with such groups as the Association of American Colleges, the North Central Association of Colleges, the New England Association of Colleges, the Southern Association of Colleges, the American Association of Junior Colleges. More understanding cooperation might result.

The specialist at A.L.A. Headquarters should be one who has a sympathetic understanding of the viewpoint and needs of the college library. He might keep aware of the college trends and needs in close cooperation with the college representatives on the A.C.R.L. Board of Directors, and aid them in service to their group and toward higher standards for every college library.

Fina C. OtT

\section{Engineering School Libraries}

In order that this statement on behalf of the engineering group might be representative and not simply one member's opinion, an expression of views was sought from a score of active librarians representing varying types of engineering libraries, stretching from Maine to Colorado, from Michigan to Georgia. The replies differed markedly, revealing wholesome independence of thought; they varied from the extreme of one librarian who felt such an agency useless and not worth the expense involved, to that of another who named ten fields of service in which it could give much needed help.

Since the inquiry was begun, committees, both of A.L.A. and A.C.R.L., have been appointed to study the problem in its larger aspect. Nevertheless, it may not be amiss to record the reactions of our group, expressed before this action was known.

Those who question the value to our section of an agency planned to serve college libraries in general, stress the special nature of engineering libraries. Our collections, they point out, emphasize science and technology and touch only lightly on the humanities material which is the meat of the liberal arts college. For personnel we seek (though too rarely find) persons with scientific or technological background. Our problems, they feel, are not administrative but inherent in the nature of the material we handle and the special needs of our clientele.
From this basic position the argument runs that it is most unlikely that a representative could be found who, having to be all things to all college libraries, could be depended upon to understand the particular problems of engineering libraries, especially in these days of rapidly changing methods in scientific and technological education. Many, relating instances of having appealed to A.L.A. Headquarters for help without result, expect to find in the future, as in the past, greater satisfaction in their relations with Special Libraries Association and with the professional societies: S.P.E.E., A.S.M.E., A.S.C.E., S.A.E., and others.

Between those who are not interested and those who are, a few sit on the fence. They fear duplication of effort with the societies just named. They feel the need of the service but doubt very much whether the plan proposed by the A.L.A. Executive Board-a reorganized Department of Information and Advisory Services-will fill the needs of college libraries, let alone engineering libraries. Some are skeptical but are willing to be shown. The proposed agency might be of some use if the director came to his job with a special interest in engineering libraries, etc.

Among those who definitely favor the proposal there is a feeling that the various sections of A.C.R.L. have enough problems in common to justify the establishment of a center of service. They recognize that no 
person chosen for such a position can be at the same time an expert on humanistic studies, on agriculture, on teacher-training, and on science and technology, but they feel that a competent person of wide knowledge, broad sympathies, and resourcefulness could bring together a fund of information and a common pool of library experience upon which any librarian in A.C.R.L., whatever his section, could draw with profit. But the person chosen should be someone of marked ability and should have a free hand. Whether he would fall into the office ruts which some think typical of A.L.A. procedure, would depend on getting the right man-or woman.

I feel strongly that the ayes have it. We do have much in common with the libraries of all sections of A.C.R.L. As librarian of a very active technical institute where the strenuous life is our norm, I encounter daily administrative problems similar to those of the college library, the university library, and the university's engineering library. For example: What are other libraries doing to improve standards for personnel? Where draw the line between professional and nonprofessional? What library staffs have gained "academic status" and have they found in it any advantages? How far, if at all, should a personnel office control qualifications and salaries of library staff members? What are reasonable vacations for different grades of staff? What institutions have succeeded in bringing their department libraries into the central library building? If the library literature, after being ransacked, supplies the answers, well and good; but too often with us it has been necessary to enter an appeal to the good nature of ever-patient and always helpful Ernest J. Reece at Columbia. If the proposed advisory service had existed at Chicago it could have helped promptly on such problems.

The reference librarians of engineering libraries could utilize the proposed service in almost unlimited ways, if the director were successful in persuading librarians generally to file with him their annual reports, their statistics, information as to their special collections, special studies in progress, copies of their bibliographies, rules and rates of their microfilm and photostat services, plans of their new buildings, etc.

At first mainly an officer for collecting, coordinating, and supplying information, the director might in time leave most of these duties to a trained staff and devote himself increasingly to the advisory side of his office, helping to improve, on the one hand, standards of library personnel, salaries, and working conditions; on the other hand, standards of service to students, faculty, alumni, and outsiders. He should soon be able to give circulation to new ideas, initiate cooperative enterprises, and encourage closer relations with foreign educational institutions. For some projects he might prepare the ground, leaving execution to the sections and their committees; on the other hand, some undertakings, proposed at section meetings, might be entrusted to him to carry out.

Those of the engineering section who cite their greater benefit from Special Libraries Association overlook a parallel which argues for the affirmative. For, if at meetings of S.L.A. they profit by the experience of many diverse types of libraries, so within A.C.R.L. they can profit by the marshaled experience of the several types of libraries that compose it. For help on the more specialized problems growing out of the special needs of our engineering and scientific clienteles we can still turn to our colleagues within the section and within the professional societies, by correspondence and through meetings and committee work. But a general college advisory service, properly headed and staffed, can, I believe, render a continuous and prompt service not to be expected through correspondence or committees.

William N. Seaver

\section{Junior College Libraries}

The more than five hundred junior colleges of the country vary widely in educational programs, size, and support. Their libraries vary equally, and the services which they might require of a college advisory office would vary equally. As the "frozen" director of the Junior College Libraries Section of the A.C.R.L. and particularly as one no longer 
affiliated with a junior college library, I felt it advisable to supplement my own convictions by consulting the officers and some members of the section. ${ }^{1}$ Specifically, I asked two questions: the first, an inquiry as to the desirability of establishing such an office; the second, a query as to the special services which might be rendered to junior college libraries. The reactions embodied in this brief report are the result of this collaboration. A vain effort was made to include reactions of junior college administrators as well.

Without exception, the junior college librarians consulted approved the establishment of a strong centralized office, set up as a clearinghouse for college and reference library problems. The conviction that the consultant should be an individual of marked ability and "real" authority, responsible to the A.C.R.L., was widely held. Although no inquiry as to financing was made, more than one librarian called attention to the necessity for adequate financing. If the proposed A.L.A. budget for support of an "advisory and information service," supplemented by whatever additional sum may be pledged by the A.C.R.L., is not sufficient to attract a leader into the position, it is my personal belief that A.C.R.L. support of the project should be withdrawn. Experimental years are crucial years, and the initiation of this project should be undertaken by a college library specialist whose qualifications would be a fair guarantee of its success.

Among the services such an office could offer or promote, the following would be of value to junior college librarians:

r. Book selection. An evaluation of new reference books and periodicals on the basis of probable use at the junior college level. The publication of a supplement to the Shaw and/or Mohrhardt list. In addition, a new monthly, bimonthly, or less frequently published book list covering current materials considered especially desirable for junior college purchase in various subject fields, both general and technical.

2. Planning library buildings. Though junior college libraries are represented in the litera-

1 Wave L. Noggle, Virginia Junior College; Mary Harrison Clay, Northeast Junior College; Mary Eliz abeth Ambler, Blackburn College; Mary Vick Burney, University of Tennessee Junior College; Sister Mary Bernadette Phillips, Georgetown Visitation Junior College; Mrs. Winifred Wright Schlosser, Herzl Junior College; Winifred Evelyn Skinner, Pasadena Junior College; Lola Rivers Thompson, John Tarleton College. ture dealing with college libraries, specific studies and plans are rare. Blueprints at various cost levels, designed to serve the needs of junior colleges of various sizes and varied curricula. Names and addresses of architects and of dealers-the latter to accompany lists of minimum, moderate, and desirable equipment, since, as Miss Clay notes, administrators sometimes plan and furnish libraries before a librarian is appointed.

3. Reference and advisory service through a study of the material already available in the Headquarters Library and through the acquisition of additional articles, studies, surveys, annual reports, and the like relating to the junior college library. Specific problems concerning adequate financing, staff, selection of book dealer or periodical agent, or the like might be considered by the consultant or referred elsewhere.

4. Research. The office should undertake some, encourage and supervise other, studies of junior college library problems. Might it be possible to develop a file of copies of relevant questionnaires sent out by junior colleges or by graduate library schools?

5. Statistics. Standards and definitions for keeping records should be adopted; statistics concerning junior college libraries should be collected and published. Previous coverage by both A.L.A. and the Office of Education has been inadequate or has failed to reach publication.

6. Supplement present resources for teaching the use of the library. Develop a satisfactory film for teaching use of the library in junior colleges and small colleges. Emphasis should be on teaching rather than entertainment value. Films available now are not well suited to junior college use.

7. Stimulate professional growth in junior college librarians and assist administrators in gaining an understanding of what adequate library service should be and in recognizing the library as an integral teaching unit in the college.

A number of other activities might be mentioned: cooperating with local or regional agencies in revising or devising adequate standards; representing the needs of junior college libraries to boards or corporations making grants to libraries; assisting in placement service. These suggestions are simply indicative of fields in which assistance and constructive leadership might be rendered.

Recent increased consideration of the problems of general education, as indicated by the announced adoption of the Chicago and Princeton plans and the publication of the Harvard report, might well serve to call atten- 
tion to the unique opportunities for general education which junior colleges can provide. The present and anticipated overcrowding of four-year colleges and graduate schools is likely to be reflected in increased enrolment in junior colleges. The organization of a strong, centralized office could be of great value to librarians in meeting the problems the junior college must help solve if modern man is not to become obsolete.

LoIs E. ENGLEMAN

\section{Libraries of Teacher-Training Institutions}

In discussing the question concerning advisory and information service at A.L.A. Headquarters as it would benefit the teachers' colleges, let us first of all recognize the fact that each and every institution of higher learning is faced today with the same challenge to contribute its best in an effort to meet the varied postwar problems, and that teachers' colleges are not to be confused with the original "normal schools" that concerned themselves chiefly with pedagogical methods.

General education for a broader culture and participation in the betterment of the areas they serve is definitely the concern of teachers' colleges. They have been active during the war years in restudying and revising their programs to prepare temporary teachers for the wartime shortage. At the same time, they are holding tenaciously to the standards that shall again be established for the teaching profession. They need the same information, up-to-date materials, guidance, and cooperation that the university and the liberal arts colleges need.

What can librarians contribute in the new developments in industry and education? How can they best adapt their work to the entire program of the institution and area they serve? What has been done in experimentation? How can we avoid the havoc of duplication of effort in developing certain procedures? Much has been done to chart the way, with little or no coordination to make such information available. A centralized agency that keeps in touch with work and experimentation done in other institutions could coordinate this work and develop goals and ways and means to achieve improved service. All too often we find the same generalizations reiterated year after year at conventions, in library schools, or in published literature for librarians. Will we continue to be isolationists? Or can we put forth greater effort to understand trends, to cooperate with the faculty in the entire program of instruction, to analyze, to evaluate, and to be able to offer constructive ideas in helping librarians formulate programs in programs for training teachers?

Teachers' college librarians, as one of the seven sections of A.C.R.L., would welcome a type of service at Headquarters that would:

I. Promote a unified program among the A.C.R.L. sections.

2. Insure continuity for development of such a program by cooperative experimentation.

3. Act as a clearinghouse for improved professional ideas, not necessarily answering all questions, but being able to refer them to institutions or individuals that have done outstanding research or to groups that have begun the study of topics of immediate concern.

4. Develop improved relations between librarians and instructors.

5. Study the programs for librarianship offered in library schools.

6. Advise on opportunities in international cooperation.

7. Disseminate through College and Research Libraries the educational guidance so much needed as issues change and new problems develop.

MARY FLOYD

\section{University Libraries}

At its October meeting the Executive Board of the American Library Association took action which provided that on the retirement of various specialists at Headquarters the sal- aries released thereby should be pooled into a budget to be used for supporting an "advisory and information service." In view of the widespread discussion of the relationship be- 
tween the American Library Association and the libraries which form the constituency of the Association of College and Reference Libraries and of a somewhat general dissatisfaction with the services which the American Library Association renders to academic libraries, it seems proper at this point to enquire what services might reasonably be providedand accepted. The viewpoint throughout is that of the university librarian.

There is a strong feeling in some quarters that the Association of College and Reference Libraries should evolve into an organization which will more nearly parallel that of the learned societies in order to develop the discipline of librarianship on a more professional and scholarly plane. Using this as a point of departure, what services does a learned society render its members? In the first place, it provides opportunity for the dissemination of pertinent knowledge through the medium of a journal supplemented, in some cases, by an active publication program. Second, it furnishes opportunities for its members to meet by holding conferences where ideas may be presented and problems discussed. There may be auxiliary enterprises, but these appear to be the main activities. It is worth noting that both of the above points were included in the report of the policies committee presented to the Association of College and Reference Libraries Board of Directors at the Boston meeting. How well have these objectives been carried forward? At present the journal, College and Research Libraries, is functioning at a high level and meetings are held. Is there cause for dissatisfaction then, with the present, and the contemplated, arrangement? It would seem so. The success which College and Research Libraries has enjoyed has been due to the energetic activities of a band of volunteer workers without any help in the form of even one full-time paid staff member. Meetings have been planned in the same manner. The first need to be met is assistance in publication, both of the journal and other materials, and in the planning of stimulating meetings. It seems doubtful if the contemplated reorganization can provide this specialized interest and service within the scope of its activities, particularly as problems of general concern to all librarians are due to be stressed.

In the second place, how useful will a general "advisory and information service" be to university librarians? Information perhaps, but advice, no. Even information would be apt to be limited to the collection and compilation of statistical data, unless an exceedingly competent specialist in academic librarianship can be placed on the staff. And it seems very unlikely that many university librarians would call for and be willing to accept advice unless a top-flight person were available for consultation.

In other words, the proposed reorganization at American Library Association Headquarters seems to hold little promise for university libraries. What is needed, and this seems reasonable enough, is an individual with a good background and experience in academic librarianship on the staff, who would devote his entire time to furthering the interests of this group of libraries. Suggested activities along these lines are the cultivation of mutual understanding between librarians and their colleagues in the learned societies, the planning of stimulating meetings, increasing the membership of the Association of College and Reference Libraries, the encouragement of study and research on problems of outstanding and mutual concern, and the development of an active program of publication.

Carl W. E. Hintz 


\section{Personnel}

The University of California has an1 nounced the appointment of John Mackenzie Cory as associate librarian, effective Dec. I, 1945. Mr. Cory returns to the staff after an absence of seven years and will be responsibile for the readers service departments, including reference, loan and shelf, browsing, and the branch libraries. He replaces Jerome K. Wilcox, who has recently assumed the position of librarian of the College of the City of New York.

After graduate study in librarianship at California and Chicago, Mr. Cory went to the University of Alabama as director of libraries, in charge of the reorganization and expansion of that library system. During the war he served successively as senior public library specialist, U.S. Office of Education; chief, Library Program Division, U.S. Office of War Information; and as an officer in the Air Transport Command.

$\mathrm{Mr}$. Cory will bring a valuable background of both local and general experience to the University of California Library at a time when it is preparing plans for extensive physical expansion and improved library service to the rapidly increasing postwar enrolment of the university. In addition to being a graduate of the university and its library school, Mr. Cory is familiar with the operations of the library through previous service in three of its departments. $\mathrm{He}$ has retained an active membership in the California Library Association and has shown continued interest in California library activities during his period of service elsewhere.

On going to the University of Alabama Library in 1940, at the time of the opening of its new Gorgas Memorial Library, Mr. Cory had a unique opportunity to supervise the transition of that institution's library facilities from a group of decentralized college and special libraries to a centrally administered and functionally organized university library system. During this period he experimented successfully with improved student orientation materials, specialized microfilm reading room services, and the service aspects of special materials and special collections. From his

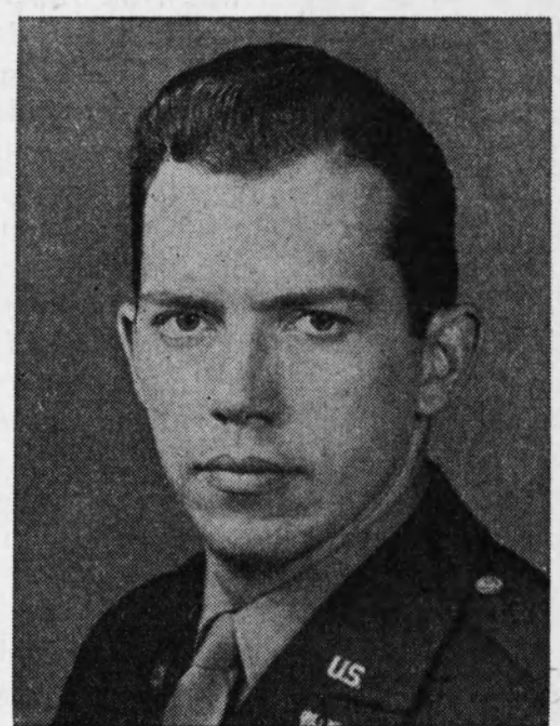

John Mackenzie Cory

wartime service with the federal government, his membership in the A.L.A. Library Extension Board, and extensive study under an A.L.A. fellowship, Mr. Cory has had unusual opportunities to obtain a broad view of library services and problems throughout the country.

In assuming his new duties Mr. Cory has expressed a desire to develop the library's services along two principal channels: expanded general library services, primarily for the undergraduate user; and specialized services for the graduate students, faculty members, and other research users of the University of California Library. Anticipating the eventual division of the library's services along these lines, with completion of the projected annex for undergraduate service, Mr. Cory is initiating several programs for the improvement of general and special services in the existing building.

Tyon N. Richardson has been appointed as $\mathcal{L}$ director of libraries of Western Reserve University and professor of English, succeeding Herbert S. Hirshberg who resigned last June to become editorial consultant for the Ameri- 


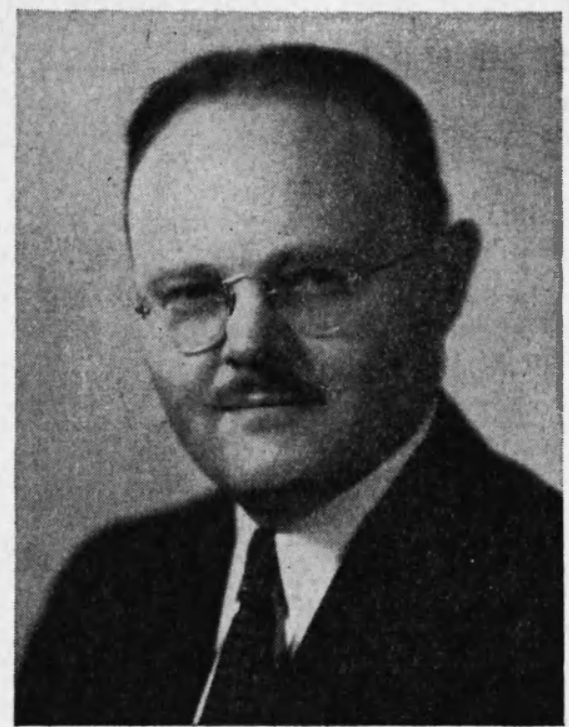

Lyon N. Richardson

cana Corporation of New York. Since that time George F. Strong, associate director, has been acting director.

Dr. Richardson has been associate professor of English at Adelbert College since 1945, editor of Western Reserve University publications, faculty adviser of the Reserve Tribune, chairman of the committee on American culture, and teacher of American literature in the graduate school. $\mathrm{He}$ is the author of $A$ History of Early American Magazines, author and editor of "Henry James," comprising a biography and selected essays, "Men of Letters in the Hayes Administration," "George William Curtis and Civil Service Reform," and is engaged in a two-volume anthology of American literature.

Dr. Richardson has been a member of the Western Reserve University faculty since 1927, when he was named an instructor in English. He was assistant dean of Adelbert College from 1929 to 1935 and assistant professor of English from 1935 to $1943 . \mathrm{He}$ received his bachelor of arts degree in 1921 and his master's degree in 1925 from Western Reserve and his degree of doctor of philosophy in I93 I from Columbia University.

Tyman W. Parker was appointed librarian of Kenyon College in Gambier, Ohio, in January upon his release from active duty in the United States Navy. He replaces

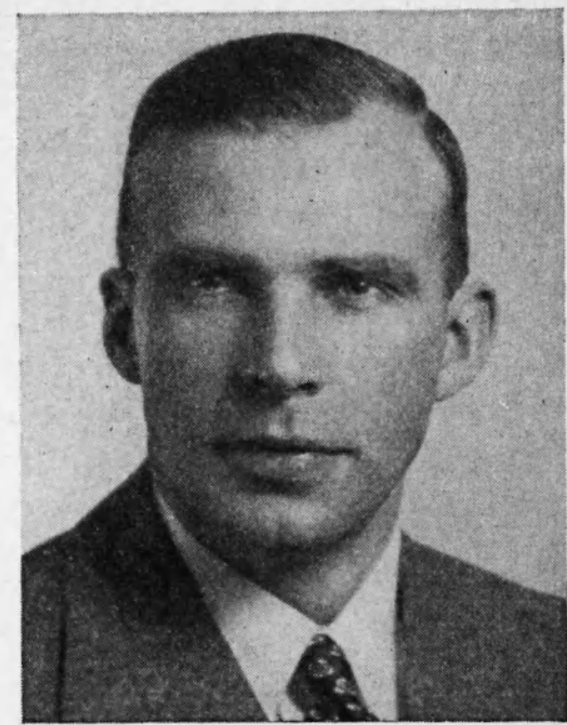

\section{Wyman W. Parker}

Eleanor M. Hickin, who has been librarian since $192 \mathrm{I}$.

Mr. Parker received his B.A. from Middlebury College in 1934. After graduating from Columbia Library School in 1935, he worked in the Reference Department of the New York Public Library as stack supervisor. He also served as librarian for the Pynson Printers, publishers of The Colophon. Summers were spent at the Bread Loaf School of English of Middlebury College as librarian while securing an M.A. in English. A year of travel on the Continent before the war increased his knowledge of the liberal arts as well as his skiing ability.

Mr. Parker was librarian at Middlebury College for four years prior to the war. There, a large collection of foreign books and a collection of rare Americana demanded concentration on administration. $\mathrm{He}$ was a director of the Vermont Historical Society and a trustee and W.P.A. personnel director of the Sheldon Museum, an historical collection of regional importance.

After two years' service in the Office of Naval Intelligence and on Admiral King's staff in Washington, D.C., he spent two years overseas as intelligence officer on General MacArthur's naval staff in Australia and New Guinea and on the staff of the admiral commanding allied submarines patrolling in the South China Sea. 


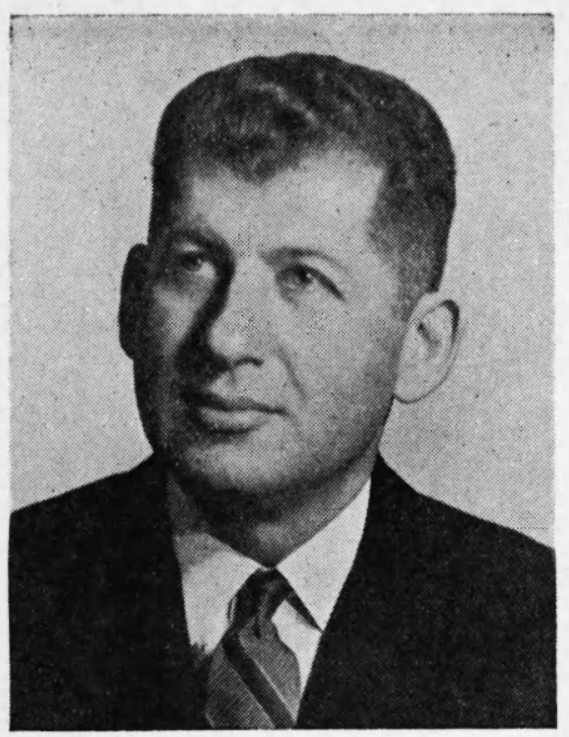

Robert L. Gitler

$\mathrm{O}$ Mar. I, 1946, after three and one-half years as an officer in the United States Navy, Robert L. Gitler became the director of the School of Librarianship at the University of Washington in Seattle, succeeding Ruth Worden, director since 1935.

While an undergraduate at the University of California, Mr. Gitler became a student assistant in the university library, and, upon receiving his B.A. degree in 1930 , he entered the School of Librarianship at Berkeley, completing the prescribed curriculum in I93I.

In July 193 I Mr. Gitler went to San Jose State College as circulation librarian. Within the next few years the college broadened the base of its curriculum from that of a teachers' college to a full liberal and industrial arts program, with a resultant growth in its enrolment from fourteen hundred to four thousand students. This provided an opportunity for administrative expansion and experimentation in his work with the head librarian and staff, and in 1936 he was charged with much of the assistance rendered the administration in the planning of the new library building. At this time Mr. Gitler acquired instructional status, teaching courses in book selection and book appreciation as well as the general course in the use of books and libraries.

On leave of absence in 1938, Mr. Gitler attended the Columbia University School of
Library Service, receiving his M.S. in 1939. In the fall of 1939 he returned to San Jose State College, where he resumed his teaching activities and was responsible for expediting the move from the old to the new library building.

From 1942 until his current appointment, Mr. Gitler served in various assignments as an officer in the Navy. He devised a new and intensive training program for the Navy's Negro personnel and was responsible for much of the interracial orientation techniques that were applied by the Navy to units with which he saw service in the Pacific theatre of the war. While overseas he was responsible for the classification of ten thousand men for skills, ratings, and education, as well as the direction of work assignments and preparation of job analysis and work distribution reports, and was active in the disposition and assignment of Negro personnel in Com.Serv.Pac. He was recalled to Washington for special duty in this field, carried on an officer training program at Hampton Institute, and concluded his naval service as commanding officer of the Stewards Mates School, Bainbridge, Md.

Before entering the service, Mr. Gitler was active in professional library associations, serving on numerous committees and holding offices. For 1940-4I he was chairman of the college and university section, California Library Association. He has also contributed to library and educational periodicals.

\section{George A. Osborn}

YEORGE A. OSBORN retired from the li$\checkmark$ brarianship of the Rutgers University Library last summer, on June 24 , 1945. He had served in the library of his Alma Mater continuously for more than fifty years, since his freshman year as a student in 1893 . Even as a student assistant he had quickly absorbed principal responsibility for the library, continuing as its administrator without the title for a number of years after graduaton, and receiving appointment in 1907 as the first fulltime librarian of the institution. Even as student "heir presumptive" he converted some 28,000 volumes into a library in fact, and went on over the years, with inspired industry, skill, and perseverence, to build that small college library into a major university library with holdings of half a million. His great achieve- 
ment has left a rich legacy not only to Rutgers University but also to librarianship.

The achievements of George A. Osborn in a lifetime of service to Rutgers University and its library reflect a very vital kind of librarianship that seems to belie in many ways the kind of man this librarian was. His modesty and self-effacement were innate qualities so pronounced as to suggest at times the monastic, yet his sense of purpose and conviction was so strong as to inspire the confidence of others and overcome all obstacles.

The librarianship of George Osborn of Rutgers may best be characterized by these attributes: It reflects a broad knowledge of materials and appreciation of their importance; it signifies a devotion to scholarship and to the service of scholarship; it is based on a complete devotion both to the ideal of service and to practical realization of the ideal; it places the individual library user at the focal point of the library, its purposes and its services; it exemplifies an industry and persistence which cannot fail to achieve; it is a practical and productive kind of librarianship which never allows means to obscure or defeat ends; and it is a librarianship that is leavened with a quiet sense of humor and a generosity of spirit that carry the librarian over the rough places.

Harold F. Brigham Indiana State Library

\section{Frank K. Walter}

The many friends of Frank K. Walter, who died on Oct. 28, 1945, may wish to reread the tribute paid to him by J. Christian Bay in the September 1943 issue of College and Research Libraries.

\section{Appointments}

Charles W. David, director of libraries of the University of Pennsylvania, has announced three major administrative appointments. Dorothy Bemis has been given leave as librarian of the Lippincott Library of the Wharton School of Finance to act as assistant to the director. Arthur T. Hamlin, former research assistant in the university library's reference department and more recently research analyst in the Office of the Chief of Naval Operations, is chief of service to readers. Rudolf Hirsch, formerly director of the Philadelphia Bibliographical Center and more recently in Europe on overseas duty with the Office of War Information, has been named as chief of technical processes. Miss Bemis will continue to act in an advisory capacity to Harriet Lawrence, acting librarian of the Lippincott Library.

Jack Brown, assistant in science and technology, New York Public Library, has been appointed assistant librarian of Brown University.

Robert J. Stockho, recently released from military service, has been appointed reference librarian of Union College, Schenectady, N.Y.

Dorothea Singer, formerly chief reviser at the School of Library Service, Columbia University, became senior cataloger of the Law Library of New York University on February I.
Donald A. Sinclair, recently released from the Army, has returned to the Rutgers University Library as curator of New Jerseyana.

William B. Wood is now librarian of the Gordon College of Theology and Missions in. Boston.

John B. Stratton, ex-Army, has become assistant circulation librarian of the Ohio State University Library.

Jane Baker Hobson left the Brattleboro, Vt., Public Library, where she had been librarian since I94I, to accept the position of head of circulation of the University of Maryland at College Park.

Frances Farmer has been appointed law librarian of the University of Virginia.

Arthur Weston, professor in the classics department of Lawrence College, Appleton, Wis., has been appointed librarian.

G. S. Baillie was recently appointed librarian of the Georgia Teachers College, Collegeboro. Prior to this appointment, Mr. Baillie was a member of the library staff at Stephens College and more recently at the University of Missouri.

Virginia Murphy recently accepted the coordinate college librarianship at the University of Georgia where she will develop and direct the library program for freshmen. Miss Murphy has formerly been at Mississippi State College for Women, Duke University, 
and the Roanoke, Va., Public Library.

Roberta M. Ryan, former assistant in the Law Library of the University of Virginia, has been appointed head of the circulation department at the Georgia State College for Women, Milledgeville.

David C. Duniway began his new duties as state archivist at the Oregon State Library on January 5. Mr. Duniway has been employed by the National Archives at Washington for the past eight years and has been the field representative for archival work for the Office of Price Administration on the West Coast. He has also served as secretary of the American Association for State and Local History for the last five years.

Lois Baker, law librarian of the University of Oregon, is on leave of absence for a year. Rita Ridings, reference librarian on leave from the University of Wyoming Library, is law librarian of the University of Oregon during Mrs. Baker's absence.

Jean E. Meyer has been appointed union cataloger for the Oregon State System of Higher Education.

Lester J. Cappon has resigned as associate professor of American history of the University of Virginia to accept a position as archivist of Colonial Williamsburg and research editor of the Institute of Early American History and Culture, which is sponsored jointly by Colonial Williamsburg and the College of William and Mary. Dr. Cappon, who was consultant in history and archives for the Alderman Library at the University of Virginia, will continue his connection with that library as honorary consultant in archives.

John Cook Wyllie has returned to the Alderman Library at the University of Virginia as curator of rare books, and Francis Lewis Berkeley, Jr., has returned as curator of manuscripts. Both had been in active war service.

Leroy C. Merritt, librarian of the Virginia State Teachers College at Farmville, has returned from a tour of duty in the European Theatre of Operations with the United States Army where he was assigned to the Library Branch of Special Services, Hq. Theatre Service Forces.

Robert Hunt Land succeeded E. G. Swem as librarian of the College of William and Mary on Dec. I, I945. Mr. Land had served in the Navy since March 1942. Before enter- ing the Navy he was an instructor in the department of history at William and Mary and college archivist assigned to research on the proposed history of the college.

E. Judson Humeston, Jr., has been appointed librarian at Kansas State Teachers College, Pittsburg, to succeed Ralph A. Fritz who became librarian at Pennsylvania State Teachers College, Kutztown, in September 1945. Dr. Humeston is now serving in the Army and after his discharge will complete some work at George Peabody College before he takes up his duties as librarian. He was formerly on the faculty at Hollins College, Va., and has taught at the Taft School, Watertown, Conn., and the Princeton tutoring school.

Lucille Shanklin has been appointed librarian at Friends University, Wichita, Kan., to succeed Alice Beach who recently resigned. Miss Shanklin was formerly at the Hutchinson, Kan., Army Air Base Library.

Margaret Sandlin has been appointed librarian at Sterling College. She succeeds Dorothy Drury who resigned in the summer of 1945 to become librarian at the Northern Baptist Theological Seminary in Chicago.

Alleen Wilson, who has been librarian at Union College, Barbourville, Ky., during the past two years, became librarian at Baker University on January I.

Hattie Osborne, acting librarian at Baker University during the war years, has resumed her work as librarian of the Bishop Quayle Bible Collection at that institution.

Joseph B. Rounds, librarian of the Grosvenor Library, returned from service with the U.S. Army Signal Corps to active direction of the Grosvenor Library in November 1945. Julian Park, dean of the College of Arts and Sciences of the University of Buffalo, who was acting librarian during Mr. Rounds's military leave, has been appointed a trustee of the library. Dr. Park had resigned an earlier appointment as a trustee to serve as acting librarian.

Helen Crawford, formerly classifier at Iowa State College Library, is now in charge of the Medical Library at the University of Wisconsin.

Mary C. Devereaux, on leave of absence in the service of the Army Air Corps since 1943, resumed her duties as assistant professor of library science at the University of 
Wisconsin Library School in September 1945.

Victoria Hargrave, formerly extension librarian at Iowa State College, is now librarian of the Lane Library at Ripon College, Ripon, Wis.

Joseph S. Jackson, formerly an assistant in the Kenyon College Library, Gambier, Ohio, became librarian of Carroll College, Waukesha, Wis., in September 1945.

Louis Kaplan, who has been in the U.S. Navy since March 1943, resumed his duties as reference librarian at the University of Wisconsin on Dec. I, 1945. Helen Northup is associate reference librarian at the university library.

Rachel Katherine Schenk, formerly circulation librarian at Purdue University, became assistant professor of library science at the University of Wisconsin Library School in September 1945.

Loretta Swift, formerly head cataloger at Stephens College, Columbia, Mo., is now assistant librarian at Lawrence College.

Donald A. Woods became librarian at the Milwaukee State Teachers College in September 1945 . He had previously been librarian of the Wisconsin State Teachers College Library, Superior.

Eva Bowden has been appointed librarian of Lander College, Greenville, S.C.

Mrs. Mae S. Johnson has been appointed librarian of Benedict College, Columbia, S.C.

Betsey Fleet, formerly reference assistant at Washington and Lee University and Virginia Military Institute and recently a lieutenant in the WAVES, became reference librarian at Kent, Ohio, State University Library on March I.

Robinson Spencer, formerly librarian of Willamette University, became cataloger at the Library of the College of the Pacific, Stockton, Calif., in August 1945.

Alice Charlton, formerly chief cataloger at the John Crerar Library, has been appointed acting chief of the Bibliography Division of the Stanford University Libraries.

Kathrine E. Johnson has been appointed as engineering librarian of the Stanford University Libraries.

Melvin C. Oathout, until recently in the United States Coast Guard, has been appointed librarian of the Hopkins Transportation Library of the Stanford University Libraries.

William Howard Brett has been appointed to succeed George Farrier as stack supervisor at the University of California, Berkeley. Mr. Brett entered the Army Signal Corps as an officer in July 1942 and from March 1945 until his discharge in October served as director of the School for Unit Librarians in London and in Paris.

Douglas W. Bryant has been appointed assistant librarian in charge of the administrative office at the University of California, Berkeley. From 1942 to I 945 Mr. Bryant served as head of the Technical Information Branch and the Airplane Handbook Section of the Navy Department's Bureau of Aeronautics in Washington. Before entering the Navy he was assistant chief of the Burton Historical Collection, Detroit Public Library.

\section{Retirements}

Mabel Zoe Wilson has retired after fortythree years as librarian of Western Washington College of Education, Bellingham.

Alice D. McKee, reference librarian of Ohio State University, retired on Dec. 3I, 1945. She has been on the staff since I9I2.
Mrs. Catherine Lipop Graves has retired as law librarian of the University of Virginia after thirty-three years of service.

Anna M. Tarr, librarian of Lawrence College, Appleton, Wis., since 1926, retired on February I. 
The American Book Center for War Devastated Libraries, Inc., came into existence in April I945 as an outgrowth of a conference held by the Department of State and the Library of Congress. It is sponsored by the Joint Committee on War Devastated and Other Libraries of the Council of National Library Associations and is recognized as the coordinating agency for restocking libraries in Europe and the Far East. The center proposes to conduct a national campaign to stockpile printed materials useful for scholarly investigation and for the physical, economic, industrial, and social rehabilitation of allied nations. Such materials will be solicited as gifts from publishers, learned societies, libraries, educational institutions, scholars, scientists, and other individuals throughout the United States. Control of the center is through the following officers and board of directors: Sidney B. Hill, president; Frederic G. Melcher, vice president; Wyllis E. Wright, secretary; Eleanor S. Cavanaugh, treasurer; Milton E. Lord, chairman; Luther H. Evans, Harry Miller Lydenberg, Keyes D. Metcalf, Brother Aurelian Thomas, and Edward N. Waters. The center early announced the policy of making its services available, in the beginning, only to the allied nations but reserved the right to include other nations if and when inclusion was recommended by the Department of State. The principal program has been delayed through difficulties of finding financial support. It is now hoped that sufficient funds may be realized through various national organizations in this country which represent the interests of each of the recipient nations. Meanwhile, plans have gone forward to distribute stockpiles of government documents and miscellaneous materials in the hands of certain government agencies in advance of the national stockpiling campaign.

The Division of Surplus Property Utilization, U.S. Office of Education, issued a memorandum on Dec. 5, 1945, which deals with state education agencies for surplus property. The Surplus Property Act of 1944 had provided generally "to channel surplus goods on the basis of need to nonprofit school systems, libraries, universities," etc. To help carry out this program the legislature or governor of each state was requested to designate or create an agency by Jan. I, I946,

\section{News from}

with responsibility to represent the various public and private educational institutions within a state and to cooperate with the U.S. Office of Education. Among other duties, this agency, to be known as the state educational agency for surplus property, is responsible for collecting estimates of need for items of surplus property from all eligible educational institutions in the state and for transmitting promptly to these institutions data and information supplied by the U.S. Office of Education relative to quantities, condition, prices, etc., of surplus property.

The Journal of the American Institute of Architects published in November 1945 a list of "One Hundred Books on Architecture" suitable for public libraries, which had been compiled by Dean Turpin C. Bannister under the direction of the institute's committee on education. A choice of twenty-five titles is indicated for smaller libraries. Reprints of the list are available on request from the institute, I74I New York Ave., N.W., Washington 6, D.C.

The Journal of Higher Education for October 1945 carries an article on "The Program of the Library School" by Carl M. White, director of libraries, Columbia University.

Higher Education Looks Ahead (Bulletin 1945, No. 8, U.S. Office of Education) by E. V. Hollis and R. C. M. Flynt is a useful compilation of reports of postwar plans in the colleges and universities of the country. Among the topics discussed are forces and agencies that condition state and local planning, state-wide planning for postwar higher education, institutional organization for planning, actions taken and proposed in important areas of planning, and selected institutional plans. The eleven-page bibliography at the end of the , bulletin was prepared by Mrs. Elizabeth N. Layton.

A compilation useful to veterans and to librarians assisting veterans is $A$ Guide to $\mathrm{Col}$ leges, Universities and Professional Schools in the United States, prepared under the direction of Carter V. Good for the American Council on Education at the request of the Army. The guide not only contains information about courses, degrees, and requirements, but also about such matters as housing for 


\section{the Field}

married students, opportunities for part-time work, campus regulations, etc.

In Historia, Organizacion y Servicios de la Biblioteca del Congreso de Los Estados Unidos de America (Buenos Aires, 1945. 47p.) Jorge B. Vivas reviews the history, services, objectives, collections, finances, and organization of the Library of Congress.

\section{East}

More than three hundred volumes connected with the life and work of Charles Dickens and some fifty framed prints of portraits of him and characters in his novels have recently been received by the Colby College Library. The books and pictures, together with hundreds of pamphlets and clippings, were gathered by the late $\mathrm{W}$. O. Fuller, for sixty-seven years editor of the Rockland, Me., Courier Gazette, and have been presented by his widow as a memorial to him. The collection is particularly strong in guidebooks and interpretative material, but includes several complete sets and many separate volumes of the works themselves.

On February 22 the Colby College Library, in its meeting of associates, memorialized the fiftieth anniversary of the publication of $\mathrm{A}$. $\mathrm{E}$. Housman's A Shropshire Lad. Professor Carl J. Weber presented his collection of more than sixty editions of the poem, many in mint condition and exceedingly rare, to the library. Gilmore Warner, librarian, announced the publication by the library of the jubilee edition of $A$ Shropshire Lad (Southworth-Anthoensen Press, \$3), edited by Dr. Weber and containing notes and a detailed semicentennial bibliography of the editions.

During the summer quarter of 1946 two courses will be offered at Kent State University by a newly formed department of library science, which will offer credit to teacherlibrarians. These courses are a response to the North Central Association's requirements that school librarians must have a minimum of six semester hours in library science and in some cases must have a minimum of sixteen semester hours. In the fall quarter a series of six courses will begin and will run throughout the year, making it possible to have a minor in library science in the school of educa- tion. The courses in the summer quarter will be taught by John B. Nicholson, Jr., librarian, and Mrs. Ola W. Whetten.

Charles W. David, director of libraries of the University of Pennsylvania, reports that the library received as a gift a small collection of manuscript city records from Gross Gerau in Hessen, Germany, extending from 1583 to 1642. The donor's slip which accompanied the gift stated, "They were taken from a prisoner in a Nazi camp by an American who sent them to us." Dr. David writes further:

We feel that these records are of value to the city of Gross Gerau, and that it would be wrong for us to keep them here. We are accordingly taking steps to return them to the city of Gross Gerau at the earliest possible moment. We feel moreover that this small transaction is worthy of some publicity, since we are anxious to exert what influence we can against the impulse to appropriate the cultural possessions of a conquered enemy.

The University of Pennsylvania Library opened an exhibition of Franklin's work on electricity to the public on January 19 to coincide with founder's day. Many private collectors and Philadelphia institutions loaned unusual items for this exhibit.

The Colby College Library celebrated its homecoming on Nov. Io, 1945, with two exhibitions of interest. Between 150 and 200 copies of newspapers sent back by Colby alumni from military fronts and cities all over the world were displayed in the main reading room. In the treasure room representative items from the book arts, Robinson, and Hardy collections, the "sentimental library" of association items, manuscripts, and letters, and early and foreign imprints were exhibited.

Baldwin-Wallace College, Berea, Ohio, has announced a gift of $\$ 125,000$ from George W. Ritter, an attorney of Cincinnati, for a library building to be known as the Ritter Library in memory of Mr. Ritter's parents. It will provide space for one hundred thousand volumes, and will be equipped to meet the needs of a thousand students. James W. Pugsley is librarian.

The University of Akron's Bierce Library is working on blueprints for an addition to the present library building for temporary use. A new library building is planned as one of a group of new university buildings, a project made possible by a gift of $\$ 605,000$ from the 
rubber companies in the Akron area in October 1945 .

In April 1945 the Bierce Library, University of Akron, cooperating with the Akron Public Library, began publication of the bulletin Facts and Figures, for business and labor interests. Topics covered, under the general heading of "Tools for Business Planning" have been: (I) Transition from war to peace, (2) How to keep abreast of happenings in Washington, and (3) Designs for community planning. Josephine A. Cushman is librarian.

Goddard College Library has been loaned a private collection of about two thousand volumes by a member of the Goddard College faculty. The collection includes modern poetry, sets of modern and nineteenth-century authors (among them D. H. Lawrence, Christopher Morley, and Thoreau), first editions, signed editions, and sets of Transition, New Writing, and Print.

\section{Middle West}

The Macalester College Library recently completed cataloging its Neill Collection of old and rare books and manuscripts and opened the collection for the use of students, faculty, and other scholars, according to an announcement made by William P. Tucker, librarian. The collection-chiefly history, biography, and description and travel pertaining to the early Minnesota region-consists of some 1600 books in addition to manuscripts and pictures. Other valuable items include early Americana in general, a few incunabula, early Bibles, and Bibles in many languages, including some of the American Indian tongues. Manuscript items include letters written by William Penn, George Washington, Henry Wadsworth Longfellow, William Dean Howells, William Cullen Bryant, and John Greenleaf Whittier. The collection was given by Edward Duffield Neill, pioneer educator, historian, minister, and public official, who at one time served as private secretary to President Lincoln and as American consul in Dublin.

A new program for the preparation of teacher-librarians has been introduced at Western Michigan College of Education, Kalamazoo, beginning with the academic year 1945-46. The program is supported jointly by the college and by the W. K. Kellogg Foundation which has set aside $\$ 44,000$ to be used over a five-year period. The new department of teacher-librarian training is under the direction of Alice Louise LeFevre. The curriculum provides opportunity for candidates for the A.B. or the B.S. degrees to present either a major of twenty-four semester hours or a minor of fifteen semester hours in library science and to meet the requirements for state certification. The courses are planned with the needs of school librarians in mind, with emphasis upon the function of the school library as a coordinating agency with public and county libraries in the community. Quarters in the library building include a library room to house the professional and study collection of books. Dorothy W. Curtiss, assistant professor at the Columbia University School of Library Service, organized and cataloged the initial book collection.

The Beech Aircraft Corporation of Wichita has given five thousand dollars to the University of Wichita for the purchase of technical books and periodicals in the field of aviation. Other libraries and institutions in the area will be encouraged to make use of the materials.

A valuable collection of historical documents was recently given to the Abbey Library at St. Benedicts College, Atchison, Kan., by the Rev. R. F. Paquette of Newport, Mich. Nineteen of the I40 pieces are parchment manuscripts-papal bulls, rescripts, and letters, dating from about 1550 to 1800 , with a few from the duchy of Venice dated about I790. Most of these are in Latin, some are in Italian. Most of the documents on paper are manuscripts, but a few, including ten passports (Papal States, Italy, Sardinia), a number of hunting licenses, permits to sell liquor, etc., are filled-in forms, all with dates between 1840 and 1860 . Five original letters dealing with the Napoleonic wars, and apparently so far unpublished, are included in the collection. The only pieces in English are two letters of introduction for the sons of the Marquis Torlonia (Rome). One of them is dated at Leghorn, Feb. 26, I803; the other, at Birmingham, Sept. I9, I804.

In order to make the Ottawa University Library more useful to the students and faculty, the librarian, Lucille Childears, has rearranged the books according to the divisional plan. Books most in demand are placed 
on open shelves in divisional groups corresponding to the divisions of the college curriculum. Duplicates and more specialized books remain in the stacks. The arrangement increases administrative problems but has proved quite satisfactory.

An article by Ralph A. Fritz, former librarian, and Esther Park, reference librarian, State Teachers College, Pittsburg, Kan., entitled "Seeing Contemporary Affairs" appeared in the October 1945 issue of See and Hear, a new periodical on audio-visual learning.

\section{South}

The Classified List College Libraries and the Classified List of Reference Books for College Libraries, which were distributed in I 940 by the Southern Association of Colleges and Secondary Schools, are now being revised under the editorship of W. Stanley Hoole, director of libraries, University of Alabama. A committee under the chairmanship of Mrs. Brainard Cheney, reference librarian, Joint University Libraries, Nashville, is revising the list of reference books; and a committee, of which Virginia Trumper, serials librarian, Woman's College of the University of North Carolina, is chairman, is responsible for the list of periodicals. The work of the committees is being supervised by a college library advisory committee of which A. F. Kuhlman, director, Joint University Libraries, is chairman. It is hoped that the revised lists will be available by October 1946 .

The University of Alabama Library was recently presented with approximately two hundred books by and about Edmund Burke. The collection was the gift of the widow of Colonel Hopson Owen Murfee, who was secretary of the Edmund Burke American Memorial Committee for the Original Thirteen American Colonies.

The University of Georgia Libraries recently received the personal library of John Wilkinson Jenkins, who for twenty-five years was professor of economics at the university. The gift of 1050 volumes and several thousand pamphlets, covering the general subject of economics and particularly the fields of transportation, marketing, and investments, was made by Mrs. Jenkins as a memorial to her husband.

The Georgia School of Technology Library has received a grant of thirty thousand dollars from the General Education Board. The fund will be used to purchase back files of technical and scientific journals to support research and graduate study in the engineering fields.

An Index of Indexes and Minor Collections not fully displayed in the card catalog of the Library of the University of Texas (Prelim. ed. Austin, Library of the University of Texas, 1945. 29p. Mimeo.) is a guide to I24 different collections in the various departments of that library, which has been prepared mainly for the guidance of the Texas staff. However, since most large libraries tend to make indexes of special files and collections, it is of interest to others as an example of a well-organized guide to such sources of information. The listing of some of the collections may also be suggestive and helpful to librarians responsible for interlibrary borrowing. The arrangement is by department, and there is a fairly detailed index of subjects and proper names.

The University of North Carolina Library has been presented the personal library of the late Edward Vernon Howell, former dean of the school of pharmacy, by his nephew, Kay Kyser. The collection is especially rich in historical botanical materials, early herbals both European and American, and North Caroliniana. It also includes valuable manuscript material concerning Henri Harrisse which Dean Howell had collected with the purpose of writing a biography of that distinguished historian.

The Friends of the University of North Carolina organization has been active in the publication of the Bookmark, a leaflet of library news which appears at irregular intervals and has now reached six numbers. The present officers of the Friends of the Library are: Louis R. Wilson, chairman; John Sprunt Hill, honorary chairman; F. M. Hanes, vice chairman; Charles E. Rush, ex officio secretary; Mrs. Lyman Cotten, secretary; Mary Thornton, assistant secretary.

Wake Forest College, Wake Forest, N.C., reports that funds for a library building to cost five hundred thousand dollars are rapidly coming in. A stack capable of housing 250,000 volumes is contemplated. The library, now numbers approximately 70,000 volumes. 
Funds for a survey of the University of South Carolina libraries have been granted by the General Education Board. The survey is being conducted by Louis R. Wilson and Maurice F. Tauber.

The Greensboro Library Club of North Carolina undertook, in 1945, the listing of periodical holdings of the libraries in Greensboro and vicinity, including Greensboro College, Guilford College, and the Woman's College of the University of North Carolina. Virginia Trumper, of the Woman's College, has edited this union list and has made it available for distribution in mimeographed form.

A guide to the collection of bound magazines and important indexes in the East Carolina Teachers College Library, Greenville, has been compiled and published by Wendell W. Smiley, librarian.

The Southern Association of Colleges and Secondary Schools is planning a third work conference for the summer of 1946. W. Stanley Hoole, director of libraries, University of Alabama, is serving as the library consultant for the committee on work conferences.

During World War II the Virginia State Library microfilmed some 660,000 manuscript pages or items, most of them security copies of early public records of counties in eastern Virginia. The library also copied by photostat some 140,000 pages or items, including I 42 county record books, and restored some I 70,000 manuscripts and printed pages.

The Virginia State Library has taken over most of the extension loan service of the Extension Division of the University of Virginia. However, books in those fields in which the state library does not specialize, such as technology, are still available from the Alderman Library of the University of Virginia. By this cooperative arrangement the resources of the two largest libraries of the state support serious study and investigation.

The Alderman Library at the University of Virginia has recently issued three publications: (I) the Fourteenth Annual Report on Historical Collections, University of Virginia Library, for the Year 1943-44; (2) a facsimile of the 1828 Catalogue of the Library of the University of Virginia, number six in the University of Virginia Bibliographical Series; and (3) Iron Works at Tuball: Terms and Conditions for their Lease as stated by Alex- ander Spotswood on the twentieth day of July 1739, number five of the Publications of the Tracy W. McGregor Library.

The Alexander Macaulay Memorial Collection of the College of William and Mary now numbers about one thousand titles. The collection is a memorial to a Virginian who died in 1813 at Pasto, Colombia, in the struggle for the independence of the countries which make up Gran Colombia. It was begun at the suggestion of E. G. Swem and has been made possible through the cooperation of Enrique Naranjo, of Boston. Its purpose is to give the students and faculty an enlarged concept of the history, literature, and general culture of South American countries through the writings of authors of those countries.

The Federal Works Agency recently approved $\$ 32$,000 to defray the architect's fees for preliminary sketches for the new library building at the University of Georgia. Plans are being developed for a modular type building with subject divisional reading rooms, bookstack areas, seminar rooms, and faculty studies. It is estimated that the building, which will be named the "Ilah Dunlap Little Memorial Library," will cost approximately one million dollars.

On Nov. 19, 1945, the Friends of the Duke University Libraries met for the annual meeting. The speaker was Julian P. Boyd, librarian of Princeton University and a former student of Duke University. Dr. Boyd spoke on the subject ". . . But Written Letter Dwelleth." He discussed the broader problems of libraries in their relation to educational aims and the major aspects of responsibilities that face teachers and scholars in relation to the materials of scholarship.

On Dec. 3, 1945, the Staff Association of the Duke University Libraries held a meeting with the staff of the University of North Carolina Library as its guests. The speaker was Harvie Branscomb, dean of the divinity school and former director of the Duke University Libraries. In his address on "Library Development in Brazil," he described the work of the commission, of which he was a member, appointed by the American Library Association to visit Brazil and to advise their department of education concerning the reorganization of the National Library of Brazil.

The University of South Carolina Library 
expects to complete its reclassification from Cutter to Dewey during the next three years. The General Education Board has contributed to the project six thousand dollars outright and thirty thousand dollars on a matching basis.

During its centennial celebration, Limestone College, Gaffney, S.C., received from alumnæ several hundred documents relating to the history of the college.

The State Medical College of South Carolina has been given the library of L. M. Stokes, a trustee of the college.

Mrs. J. H. Crosland, librarian of the Georgia School of Technology, was named Atlanta Woman of the Year in Education for 1945. Last year Mrs. Crosland, who has been librarian since 1927 , obtained a grant of thirty thousand dollars to the library from the General Education Board.

\section{West}

The Regents of the University of California have authorized a survey of the book collections in the university libraries. The university has eight campuses in all, with separate institutions at Berkeley, Los Angeles, Davis, Santa Barbara, La Jolla, and Mount Hamilton. The number of accessioned volumes within the system runs to more than two million. The purposes of the survey are to assess the present strengths and weaknesses of the several collections, to ascertain possibilities of avoiding duplication within the system, and to lay the foundation for a systematic acquisitions program for the next decade. President Robert Gordon Sproul of the university appointed Fulmer Mood to conduct the work of the survey and designated him special assistant to the president. Dr. Mood has taught at Berkeley and Harvard and served as librarian at the Redlands University from I939 to I94I. More recently, he was chief of archives, Historical Division, Army Air Forces Headquarters, Washington. Dr. Mood began work on the survey in January 1945 and expects to announce its completion sometime during 1946.

The Library Council of the University of California is concerned with library problems affecting more than one campus, with consistency of policy and practices, and with the appropriate distribution of responsibility. The council is composed of the dean of the school of librarianship, the librarian of each campus having a single library, and the ranking librarian of campuses having more than one library. The executive committee, consisting of the head librarians of the university's libraries at Berkeley and Los Angeles and the dean of the library school, is empowered to prepare agenda for meetings and to deal with questions affecting only the university's larger libraries. Because of its small size, the executive committee has no formal chairman, but it does have a secretary whose position will rotate biennially between the Berkeley librarian, the Los Angeles librarian, and the dean of the school of librarianship, in that order. Donald Coney is secretary for the years 1946 and 1947 , after which the position will pass to Dr. Powell at Los Angeles.

Pacific College Library, Newberg, Ore., has assembled a "Quaker Corner" of 532 volumes of biography, memoirs, history of Friends, and books written by Quakers, including religious works and fiction. The collection is being used by historians and people interested in tracing their ancestors as well as by students in church history classes.

The University of British Columbia Library has received a substantial gift from the Lady Lions Club of Vancouver. The money is being used for recreational reading collections for the residence huts and students' cooperative houses.

An increased state library appropriation of $\$ 15,000$ by the 1945 Oregon legislature has made possible the creation of the position of state archivist at the Oregon State Library. David C. Duniway, formerly at the National Archives at Washington, has been appointed to the position.

The University of California Library at Los Angeles has recently received a collection of five hundred children's books formed by the late Olive Percival.

The University of California Library recently received an interesting gift collection of musical scores from the library of Paul Steindorff, who was choragus of the university from 1912 to 1923 and a prominent member of musical circles in the Bay area. The gift was presented by his daughter, Mrs. E. A. Shafer. It includes one hundred bound volumes and approximately one hundred pieces of music, including light opera, songs, and classical music. 